\title{
Intrauterine honey infusion in Holstein Frisian cows with purulent endometritis
}

\begin{abstract}
Endometritis is one of the major gynecological problems affecting reproductive performance and economy of milk production in dairy cows. Since multidrug resistant bacteria (MDR) is widely global spread, alternative therapeutic agents is urgently needed. By the gynecological investigation of 566 Holstein Frisian lactating cows, 38 suffering from repeat breeder (RB) were showing purulent exudative endometritis (PE). Different Staphylococcus and Streptococcus spp. were isolated, identificated and subjected to antimicrobial assessment, where all tested strains were MDR with overall multi antimicrobial resistance index (MAR) 0.42 , while when be tested against Egyptian cotton honey achieved only 10 \& $20 \%$ minimum inhibitory concentration (MIC). Twenty four cows of the affected cows were included in the study were divided to three groups; (A): 6 cows did not receive any previous treatment, while (B): 10 cows did not respond to long different classic treatment and $(\mathrm{C}): 8$ cows did not receive any management and left as a control group. Both groups A \& B received I/U of $100 \mathrm{ml}$ of full strength Egyptian cotton honey infusion day /day for three successive infusions until purulent exudate clearance or up to three successive infusions. Success results were judged by conception rate (CR), where it was $80 \%$ for group A and $70 \%$ for group B with overall conception rate for all honey treated cows of $75 \%$. It was concluded that $\mathrm{I} / \mathrm{U}$ honey is a very effective successful management for bovine PE especially those antibiotic none-responding since it would clear the pyogenic infection with high conception rate.
\end{abstract}

Keywords: endometritis, Staphylococcus, intrauterine infusion, honey
Volume 12 Issue I - 2019

\author{
Abdul-Hafeez MM,' Abdul-Kadder H A,' \\ Sayed AM,' Shehata $\mathrm{SH}^{2}$ \\ 'Animal Health Research Institute, Egypt \\ ${ }^{2}$ Department theriogenology, Assiut University, Egypt
}

Correspondence: Abdul-Hafeez M,Animal Health Research Institute, Assiut lab, ARC, Egypt,

Emailmohhafeez5555@gmail.com

Received: January 30, 2019 | Published: February 25, 2019
Abbreviations: MDR, multidrug resistant bacteria; RB, repeat breeder; PE, purulent exudative endometritis; MAR, multi antimicrobial resistance index; MIC, minimum inhibitory concentration; $\mathrm{CR}$, conception rate

\section{Introduction}

Endometritis is highly prevalent disease where approximately $40 \%$ of dairy cows develop a uterine disease ${ }^{1}$ having a substantial influence on bovine health and reproductive performance, ${ }^{2}$ with significant sizable economic impacts and lowering profitability to the dairy industry. ${ }^{3}$ It is frequently treated with antibiotic intrauterine infusion, but with the emergence of MDR bacterial strains the alternative antimicrobial therapy for bovine metritis and endometritis is required. ${ }^{3,4}$ Several therapeutic alternative agents proved in vitro antimicrobial activity were recommended to be tried as intrauterine infusion such as lactic acid, ${ }^{1,4,5,6}$ herbal essential oil extracts (garlic, ${ }^{7}$ neem, ashwagandha, turmeric, ${ }^{8}$ tulsi and giloy, ${ }^{2}$ hyper immune serum, ${ }^{9-11}$ endotoxins such as lipopolysaccharide of E. coli, ${ }^{9,10,12}$ low dilutions of $\mathrm{H}_{2} \mathrm{O}_{2}{ }^{13-15}$ chitosan ${ }^{16}$ or silver nanoparticles. ${ }^{3}$ Honey with the wonderful broad spectrum antimicrobial action ${ }^{17-19}$ was tried in mares. ${ }^{20}$ The present work aimed to study the potency of honey against pyogenic MDR endometritis pathogens as well as its influence for reproductive re-performance and conception rate post purulent endometritis in dairy Holstein cows.

\section{Material and methods}

Sampling, bacterial isolation and identification: Theriogenological rectal investigation of total 566 lactating Frisian cows belonging to two automatic milking dairy farms in Assiut Governorate revealed that thirty eight cows of them were suffering from exudative purulent or mucopurulent endometritis. Uterine swabs were collected aseptically for bacteriological examination and inoculated into nutrient broth media which were incubated aerobically at $37^{\circ} \mathrm{C}$ for $24 \mathrm{Hs}$. The incubated broth was subcultured by streacking on both $10 \%$ sheep blood and Mc Conkey's agar plates which were incubated aerobically at $37^{\circ} \mathrm{C}$ for another $24 \mathrm{Hs}$. The suspected colonies were identified morphologically and biochemically. ${ }^{21}$

\section{In vitro antimicrobial resistance study}

Antimicrobial sensitivity testing was adopted against 13 different antimicrobial agents. ${ }^{22}$ Resistance was judged by the inhibition zone diameter $\varnothing$ to calculate the MAR values. ${ }^{23}$

\section{In vitro honey minimum inhibitory concentration (MIC) assessment}

Pure unprocessed Egyptian cotton honey was diluted with sterile nutrient broth to prepare four dilutions $(50,20,10$ and $5 \%)$ freshly prepared just before isolated strain broth inoculation to determine its honey MIC.

\section{I/U honey therapeutic infusion}

Twenty four lactating Frisian cows with exudative PE with different RB periods were divided to 3 groups; (A): 6 cows which did not receive any treatment, (B): 10 cows which formerly received oxytetracycline deep I/M and I/U lotagen application without any improvement and (C) 8 cows were left without interference to be considered as a control group. 
Cows of both (A) and (B) groups were received I/U infusion of $100 \mathrm{ml}$ of pure full strength honey through rectovaginal technique using a sterile nelaton plast $40 \mathrm{~cm}-\mathrm{CH} 22$ catheter which be introduced by the aid of sterile metal Lugol's catheter. I/U infusion were carried day by day up to cessations of purulent exudate or up to three successive applications. All studied cows were followed up to five months to estimate their conception rates.

\section{Results}

Bacterial isolation was manifested in Table 1, while their antimicrobial resistance pattern and honey MIC against them were shown in Table 2. Individual cow data (clinical exudate, duration of $\mathrm{RB}$, etiological pathogens, replicate of honey intrauterine infusion and treatment success through conception rates) were illustrated in Table 3.

Table I Bacterial isolates form purulent endometritis (PE) exudates

\begin{tabular}{|c|c|c|c|c|c|c|c|}
\hline \multirow{2}{*}{$\begin{array}{l}\text { Investigated } \\
\text { lactating cows }\end{array}$} & \multirow{2}{*}{$\begin{array}{l}\text { Cows } \\
\text { with PE }\end{array}$} & \multicolumn{6}{|c|}{ Bacterial isolated strains } \\
\hline & & Total & $\begin{array}{l}\text { Staphylococcus } \\
\text { aureus }\end{array}$ & $\begin{array}{l}\text { Staphylococcus } \\
\text { epidermidis }\end{array}$ & $\begin{array}{l}\text { Staphylococcus } \\
\text { intermedicus }\end{array}$ & $\begin{array}{l}\text { Staphylococcus } \\
\text { saprophyticus }\end{array}$ & Streptococcus Spp. \\
\hline 566 & 38 & 48 & 15 & 14 & 9 & 6 & 4 \\
\hline
\end{tabular}

Table 2 Antimicrobial resistance pattern of differentisolated Staphylococcusspp.strains and MIC of honey against them

\begin{tabular}{|c|c|c|c|c|}
\hline \multirow{2}{*}{ Antimicrobial agent } & \multicolumn{4}{|c|}{ Percentages of Staphylococcus spp. antimicrobial resistance } \\
\hline & S. aureus & S.epidermidis & S. intermedicus & S. saprophyticus \\
\hline Amekin $30 \mu g$ & ND & 57 & ND & 0 \\
\hline Cefobid $75 \mu g$ & 53 & 43 & 0 & 40 \\
\hline Cephalothin $30 \mu g$ & 0 & 71 & 0 & ND \\
\hline Chloramphenicol $20 \mu \mathrm{g}$ & 80 & 71 & 14 & ND \\
\hline Duricef $30 \mu g$ & 100 & 100 & 100 & 0 \\
\hline Garamycin $30 \mu g$ & 53 & 29 & 14 & 0 \\
\hline Naledixic $30 \mu g$ & 20 & 71 & 0 & 60 \\
\hline Netlimycin $30 \mu g$ & 33 & 17 & 72 & 0 \\
\hline Polymyxin $30 \mu g$ & 80 & 100 & 0 & 0 \\
\hline Spectrama 10 $\mu g$ & ND & 50 & ND & 50 \\
\hline Tetracycline $30 \mu g$ & 53 & 50 & 14 & ND \\
\hline Tobramycin $30 \mu g$ & ND & 57 & ND & 0 \\
\hline \multirow[t]{2}{*}{ Unasyn $20 \mu g$} & 80 & 71 & 72 & 40 \\
\hline & 0.70 & 0.61 & 0.30 & 0.10 \\
\hline \multicolumn{5}{|l|}{ MAR index } \\
\hline & 0.42 & & & \\
\hline MIC of Cotton honey & $10 \%$ & $20 \%$ & & \\
\hline
\end{tabular}

ND, not done 
Table 3 Bacterial etiological agents of cow E.P. and influence of I/U Egyptian honey infusion management

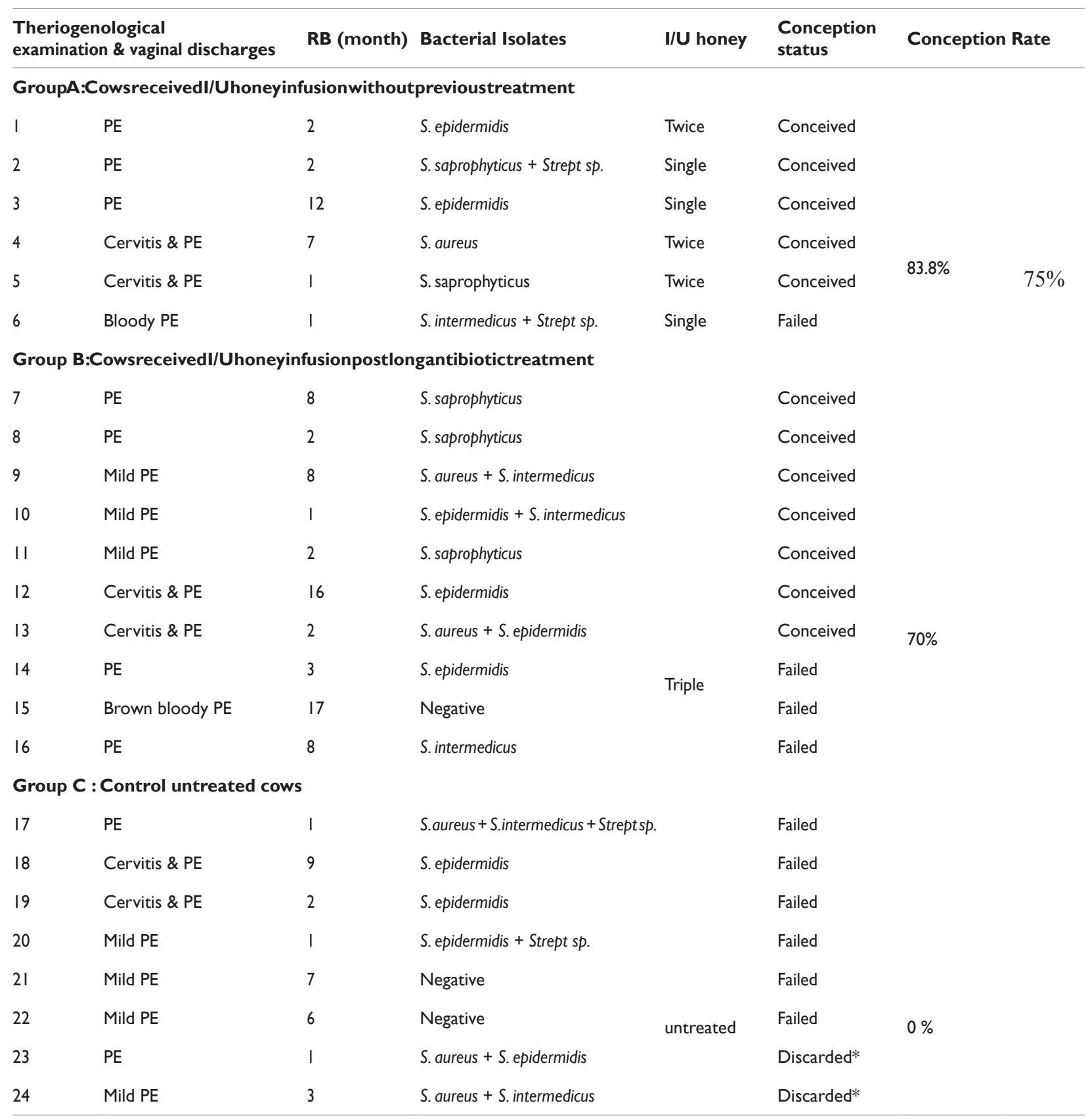

RB, repeat breeder.

*Discarded: Cows were herd discarded, be fattened and slaughtered.

\section{Discussion}

Bovine endometritis and prolonged luteal phase leading to RB (infertility complains) is significantly increased in cows with persistent infections. ${ }^{11,24}$ Well managed and profitable dairy farming requires cows with good reproductive performance, ${ }^{25}$ but uterine postpartum infection with MDR pathogens which is so common ${ }^{24}$ threaten fertility causing major cause of economic loss. ${ }^{25}$ Increased multidrug resistance has led to the increased severity of diseases caused by bacterial pathogens. ${ }^{26}$ When MAR value of Staphylococcus $s p p$. just $\geq 0.2$, is considered high $^{23}$ and might be originated from environments with misuse of antibiotics where resistance developed and spread $^{27}$ causing major problems in treatment of uterine infections in dairy animals. ${ }^{28}$ So, it is obvious that the isolated Staphylococcus $s p p$ - in the present study - were stubborn showing high MAR values (Table 2) might be managed with an alternative antimicrobial agent other than antibiotic. Against these stubborn pathogens, honey had potent antimicrobial activity since the achieved in vitro MIC value was (10-20\% - Table 2). Otherwise, as the chronic uterine infections that are resistant to antimicrobial agents may be due to biofilm production $^{14,29}$ and honey is well documented that it has a tremendous antibiofilm activity, ${ }^{19,30,31}$ itmaximized its in vitro antimicrobial action 
which might be added to its immunomodulation activation. ${ }^{32}$ As mentioned above, intrauterine alternative proved the in vitro activity against bovine uterine pathogens ${ }^{3,8}$ were advised without in vivo studies, while others failed to improve the reproductive performance when tried in vivo. ${ }^{6,28,33,34}$ Certain studies ${ }^{10,11}$ on intrauterine infusion did not differ from antibiotic application, while some of them proved to be having in vivo activity when be used alone. ${ }^{1,4,5}$ or in combination with others. ${ }^{4,14,15,35}$ Some tried intrauterine alternative agents in healthy cows to improve the reproductive performance ${ }^{6}$ away from bacterial endometritis. Moreover, most of these studies recommended alternative medicinal agents basing on the in vivo activity were judged only by clearance of uterine infection neglected the full reproductive performance not as the present work.

As honey has wonderful antimicrobial ${ }^{19,36}$ and tremendous antibiofilm activities, ${ }^{19,30,31}$ intrauterine honey infusion was tried recently in 7 old age mares (16-27years) with endometritis ${ }^{20}$ as $70 \%$ honey solution concluded that it was promising remarkable technique as improving endometrial cytological and ultrasonographic image, but did not improve fertility which might be due to animal senility. The study was biased against honey infusion where conducted with senile mares with not enough number statistically.

Contrarily in the present study, group (A) which did not receive any treatment showed the most positive results as purulent exudate clearance was achieved ( 3 cows post single infusions and 3 post twice only) with conception rate $80 \%$ (Table 3 ) and the only cow failed to conceive had bloody PE revealing other reproductive problem. Also, all cows of group (B) which were antibiotic none-responding received triple honey infusion where 7 cows had purulent exudate cessation post triple honey infusions with conception rate $70 \%$ (Table 3 ). The concluded overall conception rate of both groups (A \& B) was $75 \%$ post honey intrauterine infusion regardless to $\mathrm{RB}$ duration since five cows got received despite long RB periods (7-16months).

Consequently, among all alternative intrauterine infusion techniques, honey application appeared to be the most convenient highly effective greatly safe and economic management. It is recommended to be used routinely 30 days post parturition (before the complete uterine involution and cervix closure) to avoid development of PE causing infectious RB.

\section{Conclusion}

In case of bovine PE, intrauterine of $100 \mathrm{ml}$ of full strength honey day/day for three successive infusions is a very effective successful management even in cow antibiotic none-responding as it would clear the pyogenic infection with high conception rate $(75 \%)$.

\section{Acknowledgments}

The authors would like to thank manager directors of both Holstein cow dairy farms we adopted the work in and all members we contacted to produce our work.

\section{Conflicts of interest}

Authors declare that there is no conflict of interest.

\section{References}

1. Pages SG. Use of Lactic bacteria as a preservative strategy against metritis in dairy cows. Thesis for Ph D degree in molecular biology, Faculty of Bioscience, Bellaterra: Barcelona; 2016.

2. Sharma P, Srivastava S, Kumar R et al. Phytotherapy: An Alternative Low Cost Therapeutic Management of Endometritis in Dairy Animals: A Review. Int J Curr Microbiol App Sci. 2018;2319-7706.
3. Gurunathan S, Choi YJ, Kim JH. Antibacterial Efficacy of Silver Nanoparticles on Endometritis Caused by Prevotella melaninogenica and Arcanobacterum pyogenes in Dairy Cattle. Int J Mol Sci. 2018;19(4): pii: E1210.

4. Genís S, Cerri RLA, Bach À, et al. Pre-calving Intravaginal Administration of Lactic Acid Bacteria Reduces Metritis Prevalence and Regulates Blood Neutrophil Gene Expression After Calving in Dairy Cattle. Front Vet Sci. 2018;5:135.

5. Deng Q, Odhiambo JF, Farooq U, et al. Intravaginal lactic Acid bacteria modulated local and systemic immune responses and lowered the incidence of uterine infections in periparturient dairy cows. PLoS One. 2015;10(4):e0124167.

6. Peter S, Gärtner MA, Michel G, et al. Influence of intrauterine administration of Lactobacillus buchneri on reproductive performance and pro-inflammatory endometrial mRNA expression of cows with subclinical endometritis. Sci Rep. 2018;8(1):5473.

7. Sarkar P, Kumar H, Rawat M, et al. Effect of administration of garlic extract and PGF2 alpha on hormonal changes and recovery in endometritis cows. Asian Australas J Anim Sci. 2006;19:964.

8. Mandhwani R, Bhardwaz A, Kumar S, et al. Insights into bovine endometritis with special reference to phytotherapy. Vet World. 2017;10(12):1529-1532.

9. Peter S, Gärtner MA, Michel G, et al. Influence of intrauterine administration of Lactobacillus buchneri on reproductive performance and pro-inflammatory endometrial $m R N A$ expression of cows with subclinical endometritis. Sci Rep. 2018;8(1):5473.

10. Singh J, Sidhu SS, Dhaliwal GS, et al. Effectiveness of lipopolysaccharide as an intrauterine immunomodulator in curing bacterial endometritis in repeat breeding cross-bred cows. Anim Reprod Sci. 2000;59(3-4):159166.

11. Ahmadi M, Hosseini A, Gheisari H, et al. Preliminary trial in treatment of postpartum endometritis with intrauterine application of hyperimmune serum in dairy cows. Asian Pac J Trop Dis. 2014;4(Suppl 1):S360-S365.

12. Singuri $\mathrm{C}$. Therapeutic management of endometritis in graded murrah buffalo (Bubalus bubalis) cows using certain immunomodulars. Thesis Sri Venkateswara Veterinary Uni: India; 2014.

13. Dolezel R, Palenik T, Cech S, et al. Bacterial contamination of the uterus in cows with various clinical types of metritis and endometritis and use of hydrogen peroxide for intrauterine treatment. Veterinarni Medicina. 2010;55(10):504-511.

14. Ferris RA, McCue PM, Borlee GI, et al. In Vitro Efficacy of Nonantibiotic Treatments on Biofilm Disruption of Gram-Negative Pathogens and an In Vivo Model of Infectious Endometritis Utilizing Isolates from the Equine Uterus. J Clin Microbiol. 2016;54(3):631-639.

15. Daetz R, Cunha F, Bittar JH, et al. Clinical response after chitosan microparticle administration and preliminary assessment of efficacy in preventing metritis in lactating dairy cows. J Dairy Sci. 2016;99(11):8946-8955.

16. Molan PC,Cooper RA. Honey and sugar as a dressing for wounds and ulcers. Trop Doct. 2000;30(4):249-250.

17. Aamer AA, Abdul-Hafeez MM, Sayed SM, et al. Minimum Inhibitory and Bactericidal Concentrations (MIC \& MBC) of Honey and Bee Propolis against Multidrug Resistant (MDR) Staphylococcus Sp. Isolated from Bovine Clinical Mastitis. Global Journal of Science Frontier Research: D: Agriculture and Veterinary. 2015; 15(2):21-28.

18. Hamouda SM, Abd El Rahman MF, Abdul-Hafeez MM, et al. Egyptian fennel honey and/or propolis against MRSA harboring both mecA \& icaA genes. Int J Complement Alt Med. 2018;11(3):180-185.

19. Zineel Abidne K, Bouabdellah B. Diagnosis and Treatment of Endometritis with Intra-Uterine Infusion of A Solution of Honey $70 \%$ in Mares. J Vet Sci Technol. 2018;9(1):1000499. 
20. Quinn PJ, Carter ME, Markey B, et al. Bacteriology: Clinical veterinary microbiology. $6^{\text {th }}$ edn. Mosby Edinburgh London New York: Oxord Philadelphia St Louis Sydney Toronto; 2011.

21. Bauer AW, Kirby WM, Sherris JC, et al. Antibiotic susceptibility testing by a standardized single disk method. Am J Clin Pathol. 1966;45(4):493496

22. Subramani S, Vignesh S. MAR index study and MDR character analysis of a few golden Staph isolates. Asian Journal of Pharmacy and Life Science. 2012;2(2).

23. Azizunnesa A, Joy S and Faruk M (2011): Isolation and Identification of Uterine Microorganisms in Postpartum Dairy cows. Bangladesh J Microbiol, Volume 28, Number 1, June 2011, pp 19-23

24. Ghanemm, Tezukae, Evkotabizaikey,Osawat (2015): Persistence of uterine bacterial infection, and its associations with endometritis and ovarian function in postpartum dairy cows. Journal of Reproduction and Development, Vol. 61, No 1, 2015.

25. Swamy M K, Akhtar M S, Sinniah U R (2016): Antimicrobial properties of plant essential oils against human pathogens and their mode of action an updated review. Evidence-Based Complementary and Alternative Medicine, Volume 2016, Article ID 3012462, http : //dx.doi. org/ 10. $1155 / 2016 / 3012462$

26. Murugan K, Kavitha K, Al-Sohaibani S. Rifampicin resistance among multi-resistant MRSA clinical isolates from Chennai, India, and their molecular characterization. Genet Mol Res. 2015;14(1):2716-2725.

27. Durrani A Z, Raza M U, Canna A A (2017): An alternative therapy with ozone to avoid antimicrobial resistence (AMR) in uterine infections in dairy cattle. José M F Ferreira. Biomed J Sci \& Tech Res. DOI: 10.26717/ BJSTR.2017.01.000303
28. Le Blanc MM. 2010. Advances in the diagnosis and treatment of chronic infectious and post- mating-induced endometritis in the mare. Reprod Domest Anim 45(Suppl 2):S21-S27.

29. Kilty SJ, Duval M, Chan FT, et al. Methylglyoxal: (active agent of manuka honey) in vitro activity against bacterial biofilms. Int Forum Allergy Rhinol. 2011;(5):348-350.

30. Liu MY, Cokcetin NN, Lu J, et al. Rifampicin-Manuka honey combinations are superior to other antibiotic-Manuka honey combinations in eradicating staphylococcus aureus biofilms. Front Microbiol. 2018;8:2653.

31. Sayed SM, Abou El-Ella GA, Wahba NM, et al. Immune defense of rats immunized with fennel honey, propolis, and bee venom against induced staphylococcal infection. J Med Food. 2009;12(3):569-575.

32. Gharagozlou, F.; Ghasemzadeh-Nava, H.; Atyabi, N.; Sharifi Yazdi, H. and Akbarinejad, V: Evaluation of therapeutic effects of a 5-day intrauterine infusion of $6 \%$ Eucalyptus globulus oil solution on mares with experimentally induced endometritis with Streptococcus zooepidemicus. Iranian Journal of Veterinary Research, Shiraz University, IJVR, 2014, Vol. 15, No. 2, Ser. No. 47, Pages 145-148

33. Verma S, Choudhary A, Maini S, Ravikanth K: Evaluation of Efficacy of Herbal Intrauterine Infusion Uterofix Liquid in Treatment of Various Reproductive Disorders in Cows: A Field Study. Pharmacognosy Res 2016 Jul-Sep;8(3):173-5. doi: 10.4103/0974-8490.181459.

34. Hajibemani A, Mirzaei A, Rowshan Ghasrodashti A, Memarzadeh MR: The effect of Zataria multiflora extract on the clinical endometritis and reproductive indices in lactating Holstein dairy cows. Vet Res Forum. 2016 Fall;7(4):309-315. Epub 2016 Dec 15.

35. Abdul-Hafeez, M M. (2019): Testimony for veterinary apitherapy. Int $J$ Complement Alt Med. 2019;12(1):15-22. 